\title{
Article/Artigo
}

\section{Analysis of sandflies (Diptera: Psychodidae) in Barra do Garças, State of Mato Grosso, Brazil, and the influence of environmental variables on the vector density of Lutzomyia longipalpis (Lutz \& Neiva, 1912)}

\author{
Análise da fauna flebotomínica (Diptera: Psychodidae) em Barra do Garças, Estado de \\ Mato Grosso, Brasil, e a influência das variáveis ambientais na densidade vetorial de \\ Lutzomyia longipalpis (Lutz \& Neiva,1912)
}

\section{Mirian Francisca Martins Queiroz $^{1}$, Jane Ramos Varjão ${ }^{1}$, Sinara Cristina de Moraes ${ }^{1}$ and Gladys Elena Salcedo ${ }^{2}$}

\begin{abstract}
Introduction: Leishmaniasis is an infectious and parasitic zoonotic, non-contagious, vectorborne disease caused by protozoa of the genus Leishmania. In Brazil, the major vector of Leishmania (Leishmania) infantum chagasi (Cunha \& Chagas, 1934) is Lutzomyia longipalpis. Barra do Garças, State of Mato Grosso, was designated as a priority area by the Brazilian Ministry of Health for american visceral leishmaniasis, and it is important to identify the vector species present in this municipality. Our objective was to raise sandflies and study the influence of environmental variables on the vector density of Lutzomyia longipalpis. Methods: We performed entomological monitoring in 3 districts using Centers for Disease Control and Prevention (CDC) light traps and recorded human cases of american visceral leishmaniasis in the city. We calculated the relative frequency and richness of sandflies and applied a transfer function model to the vector density correlate with relative humidity. Results: The sandfly population was composed of 2 genera and 27 species, totaling 8,097 individuals. Monitoring identified Lutzomyia longipalpis (44\%), followed by Lutzomyia lenti (18.9\%), Lutzomyia whitmani (13.9\%), Lutzomyia carmelinoi (9.1\%), Lutzomyia evandroi (5.1\%), Lutzomyia termitophila (3.3\%), Lutzomyia sordellii (1.9\%), and 20 other species $(<4 \%)$. The male:female ratio was 3.5:1. We observed high species diversity (Da $=6.65$ ). Lutzomyia longipalpis showed occurrence peaks during the rainy season; there was a temporal correlation with humidity, but not with frequency or temperature. Conclusions: The presence of Lutzomyia longipalpis in the urban area of Barra do Garças underscores the changing disease profile, which was previously restricted to the wild environment. Keywords: Sandflies. Leishmaniasis. Time Series. Lutzomyia longipalpis.
\end{abstract}

\section{RESUMO}

Introdução: Leishmanioses são doenças infecciosas e parasitárias de caráter zoonótico, não-contagiosas, transmitidas por vetores, causada por protozoários do gênero Leishmania. No Brasil, o principal vetor da Leishmania (Leishmania) infantum chagasi (Cunha \& Chagas, 1934) é o Lutzomyia longipalpis. Barra do Garças, no Estado de Mato Grosso, é prioritária pelo Ministério da Saúde para a leishmaniose visceral americana, sendo importante conhecer as espécies de vetores presentes no município. O objetivo foi levantar os flebotomíneos e estudar a influência das variáveis ambientais sobre a densidade vetorial de L. longipalpis. Métodos: Realizou-se um monitoramento entomológico em três bairros com registro de casos humanos de leishmaniose visceral americana. Utilizando armadilhas luminosas CDC, calculou-se a frequência relativa e riqueza de flebotomíneos e aplicou-se um modelo de função de transferência para verificar a correlação da densidade vetorial com a umidade relativa do ar. Resultados: A fauna de flebotomíneos foi composta por 2 gêneros e 27 espécies, totalizando 8.097 indivíduos. No monitoramento prevaleceu L. longipalpis (44\%), seguida por L. lenti (18,9\%), L.whitmani (13,9\%), L. carmelinoi (9,1\%), L. evandroi $(5,1 \%)$, L. termitophila (3,3\%) L. sordellii (1,9\%) e outras vinte espécies (abaixo de 4\%). A proporção de machos para fêmeas foi 3,5:1. Observou-se uma alta diversidade de espécies $(\mathrm{D} \alpha=6,65)$. L. longipalpis apresentou picos de ocorrência durante a estação chuvosa; não havendo correlação temporal entre sua frequência e temperatura, mas sim com a umidade relativa do ar. Conclusões: A presença de L. longipalpis na área urbana de Barra do Garças, MT destaca a mudança do perfil da doença, antes restrita ao ambiente silvestre.

Palavras-chaves: Flebotomíneos. Leishmanioses. Séries temporais. Lutzomyia longipalpis.

1. Setor de Vigilância em Saúde Ambiental, Secretaria de Estado de Saúde de Mato Grosso, Cuiabá, MT 2. Departamento de Matemática, Universidade de Quindio, Armênia, Colômbia.

Address to: Msc. Mirian Francisca Martins Queiroz. Rua Caiapó 430, Edifício Dora, Centro, 78600-000 Barra do Garças, MT, Brasil.

Phone: 5566 4301-6619; Fax: $55663401-4983$

e-mail: mirianfmartins@uol.com.br

Received in 10/06/2011

Accepted in 01/11/2011

\section{INTRODUCTION}

American visceral leishmaniasis (AVL) is an infectious parasitic disease that is zoonotic in nature, with dogs as its main urban reservoir. In Brazil, AVL is caused by Leishmania (Leishmania) infantum chagasi (Cunha \& Chagas, 1934). Transmission is performed by sandflies (order: Diptera, family: Psychodidae: sub-family: Phlebotominae) with Lutzomyia longipalpis (Lutz \& Neiva, 1912) and Lutzomyia cruzi (Mangabeira, 1938) as the main vectors.

According to estimates by the World Health Organization, leishmaniasis is prevalent in 4 continents and endemic in 88 countries $^{1}$. AVL is endemic in Brazil, reaching 5 regions, with the occurrence of human cases in 24 states.

In 1913, AVL was first described in Brazil from an autopsy of a patient from Boa Esperança, State of Mato Grosso ${ }^{2}$. The disease has rapidly expanded into the interior of Mato Grosso (MT) following the process of uncontrolled urban expansion, coupled with the intense migratory flow between the towns of the central-south with the north and southeast of the State ${ }^{3}$.

From 2001-2006, the municipality of Barra do Garças-MT recorded 19 human cases of AVL, 2 of whom progressed to death ${ }^{4}$. The municipality is classified as a priority area for AVL, alternating between areas of moderate and/or sporadic transmission ${ }^{5}$. The presence of L. longipalpis and L. cruzi in the municipality of Barra do Garças-MT was reported between 1996 and $2004^{6}$. Seropositive dogs have also been reported ${ }^{3}$ with average positive rates of $12 \%$.

Given the above, and the increasing expansion of AVL in Mato Grosso, it became crucial to monitor the sandfly species present around residences in Barra do Garças-MT.

The objective of this study was to monitor the sandflies in neighborhoods of the City of Barra do 
Garças-MT with a record of human cases of AVL. We also studied the influence of environmental variables, i.e., temperature, relative humidity, and rainfall, on the vector density of L. longipalpis.

\section{METHODS}

Barra do Garças-MT has a population of 56,423 inhabitants and a land area of $9,079 \mathrm{~km}^{2,7}$, and is located along the Araguaia and Garças rivers (Figure 1), forming an important tourist resort, especially during June-August by offering extensive freshwater beaches that are visited by tourists from Mato Grosso, Goiás, Distrito Federal, among others. It is situated at latitude $15^{\circ} 89^{\prime} 00^{\prime \prime}$ and longitude $52^{\circ} 25^{\prime} 66^{\prime \prime}$ and is located at $318 \mathrm{~m}$ above sea level ${ }^{8}$. Its climate is Aw (hot and humid), and the dry season is from May-October and the rainy season is from November-April'. The average annual rainfall is $1,750 \mathrm{~mm}$ and the mean annual temperature is $24^{\circ} \mathrm{C}$ (minimum $0^{\circ} \mathrm{C}$, maximum $\left.40^{\circ} \mathrm{C}\right)^{10}$. The predominant vegetation type is savanna, with small portions of forest and a transition zone $e^{6}$.

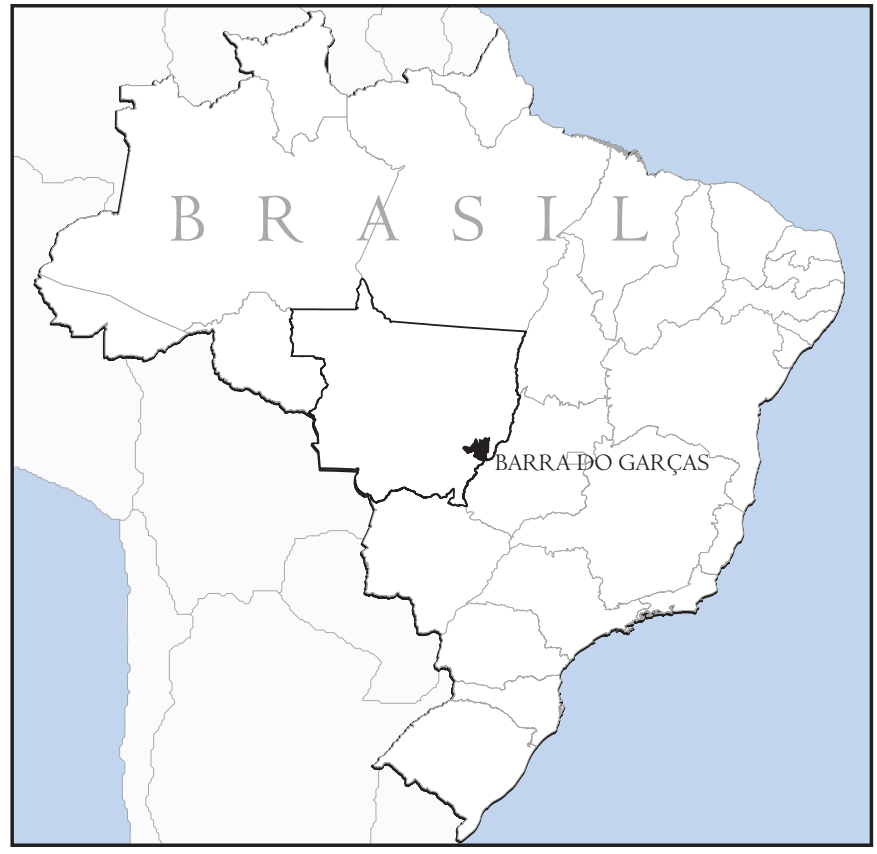

FIGURE 1 - Geographical location of the municipality of Barra do Garças, State of Mato Grosso, Brazil.

The collection of sandflies was carried out monthly in the neighborhoods of Novo Horizonte, São José, and Vila Maria. These locations were chosen because of the presence of human cases of AVL, and these are peripheral areas, located southwest of Barra do Garças-MT. Samples were collected for 4 consecutive nights between 17:00-07:00 for 24 months from September 2004 to August 2006, thereby covering different seasons.

The sandflies were collected ${ }^{11}$ from peridomestic locations with the use of Centers for Disease Control and Prevention (Atlanta, USA) light traps, with a total of 10 traps, distributed as follows: 3 in the Novo Horizonte neighborhood with the following geographic

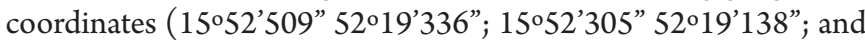

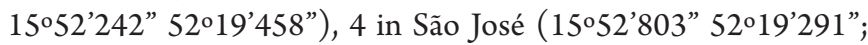

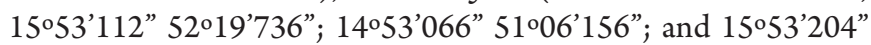

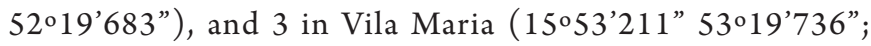

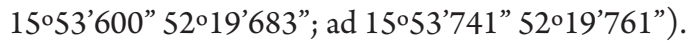

The homes were chosen to maintain favorable environmental characteristics for the life cycle of sandflies, as there were organic matter in soil (leaves, fruit, rotting logs, and feces/manure), abundant vegetation (fruit trees), livestock (dogs and chickens), and market gardens. We measured the following variables: temperature $\left({ }^{\circ} \mathrm{C}\right)$, relative humidity (\%), rainfall $(\mathrm{mm})$, and geographic coordinates. The monthly rainfall averages for the period studied were obtained from the Brazilian Company of Airport Infrastructure from the station based in Barra do Garças-MT.

The trapped insects were killed with ethyl acetate, sorted, and stored in plastic vials containing $70 \%$ alcohol for further clarification and identification at the species level by the Laboratory of Entomology, Central Level of the State Secretariat of Health of Mato Grosso (SES/MT), using phase contrast optical microscopy and a taxonomic key ${ }^{12}$. From February 2005, we also identified the sex of the collected individuals.

The relative frequency of the sandflies was calculated using percentages, and the Margalef's index (D $\alpha)$ was used to calculate wealth, translated from faunal composition ${ }^{13}$.

The influence of temperature and relative humidity on the number of sandflies was assessed using the transfer function model ${ }^{14}$. We also used analysis of variance (ANOVA) to determine whether significant differences occurred between the vector density of L. longipalpis and rainfall in different seasons - winter and summer - in the years studied. To check whether there was a correlation between relative humidity and rainfall, we applied the Bartlett correlation test ${ }^{14}$, and this was tested for up to a 2-month lag.

\section{RESULTS}

In the neighborhoods of the City of Barra do Garças-MT in the period from September 2004 to August 2006, the sandfly population was composed of 2 genera and 27 species, totaling 8,097 sandflies collected from peridomestic locations; of these, $44 \%$ were L. longipalpis. From February 2005, when we began to sex the species, the proportion of males to females of L. longipalpis was approximately 3.5:1 (Table 1).

The index of species richness $(\mathrm{D} \alpha)$ was 6.65 , where $\mathrm{D} \alpha$ values $>5$ indicate high diversity. L. longipalpis was the most abundant species, being collected in all months surveyed (Figure 2).

In the period studied, the temperature varied from $16-40^{\circ} \mathrm{C}$, and the relative humidity ranged from $24-92 \%$ while maintaining the standard of Mato Grosso, Brazil.

All cross-correlations between the frequency of L. longipalpis with temperature at different time periods were statistically zero $(p>0.05)$. However, there was a significant correlation between the frequency of $L$. longipalpis with the relative humidity in the same $(\mathrm{p}<0.07)$ and previous $(\mathrm{p}<0.05)$ month.

How had a significant correlation between the relative frequency of L. longipalpis and humidity can apply a transfer function model for a time. To better explain the model, the monthly relative humidity $\left(X_{t}\right)$, the monthly frequency of L. longipalpis $\left(Y_{t}\right)$, and the unit of time $(t)$ for each month are considered.

The model transfer function that relates these 2 series is given by:

$Y_{t}=1.17 Y_{t-1}-0.31 Y_{t-2}+2.86 X_{t}-1.14 X_{t-1}-0.765 \alpha_{t-1}+\alpha_{t}$, indicating that the monthly frequency of $L$. longipalpis $\left(Y_{t}\right)^{t-1}$ depends on the frequency of $L$. longipalpis in the previous month $\left(Y_{t-1}\right)$ and in the 
TABLE 1 - Sandflies collected with CDC type light traps from September 2004 to August 2006 in Barra do Garças-MT, by species and sex after February/2005.

\begin{tabular}{|c|c|c|c|c|}
\hline \multirow[b]{2}{*}{ Species } & \multicolumn{2}{|c|}{$\begin{array}{c}\text { From September } 2004 \\
\text { to August } 2006\end{array}$} & \multicolumn{2}{|c|}{$\begin{array}{c}\text { From February } 2005 \\
\text { to August } 2006\end{array}$} \\
\hline & frequency & relative frequency & female & male \\
\hline Brumptomyia brumpti & 44 & 0.54 & 20 & 17 \\
\hline Lutzomyia acanthopharynx & 53 & 0.65 & 25 & 11 \\
\hline Lutzomyia brasiliensis & 6 & 0.07 & 3 & 3 \\
\hline Lutzomyia carmelinoi & 734 & 9.07 & 104 & 137 \\
\hline Lutzomyia davisi & 2 & 0.02 & 2 & - \\
\hline Lutzomyia evandroi & 416 & 5.14 & 80 & 48 \\
\hline Lutzomyia flaviscutellata & 3 & 0.04 & - & - \\
\hline Lutzomyia goiana & 1 & 0.01 & 1 & - \\
\hline Lutzomyia hermanlenti & 26 & 0.32 & 12 & 7 \\
\hline Lutzomyia inflata & 4 & 0.05 & 1 & - \\
\hline Lutzomyia lenti & 1,532 & 18.92 & 274 & 408 \\
\hline Lutzomyia longipennis & 50 & 0.62 & 24 & 6 \\
\hline Lutzomyia longipalpis & 3,560 & 43.97 & 556 & 1,582 \\
\hline Lutzomyia lutziana & 2 & 0.02 & 2 & - \\
\hline Lutzomyia punctigeniculata & 2 & 0.02 & 2 & - \\
\hline Lutzomyia runoides & 2 & 0.02 & - & 2 \\
\hline Lutzomyia sallesi & 54 & 0.67 & 16 & 19 \\
\hline Lutzomyia saulensis & 3 & 0.04 & 3 & - \\
\hline Lutzomyia scaffi & 1 & 0.01 & 1 & - \\
\hline Lutzomyia shannoni & 2 & 0.02 & 1 & 1 \\
\hline Lutzomyia shawi & 1 & 0.01 & 1 & - \\
\hline Lutzomyia sordellii & 150 & 1.85 & 70 & 28 \\
\hline Lutzomyia teratodes & 16 & 0.20 & 4 & 3 \\
\hline Lutzomyia termitophila & 269 & 3.32 & 69 & 59 \\
\hline Lutzomyia walkeri & 35 & 0.43 & 10 & 21 \\
\hline Lutzomyia wellcomei & 1 & 0.01 & - & 1 \\
\hline Lutzomyia whitmani & 1,128 & 13.93 & 368 & 466 \\
\hline Total & 8,097 & 100.00 & 1,649 & 2,819 \\
\hline
\end{tabular}

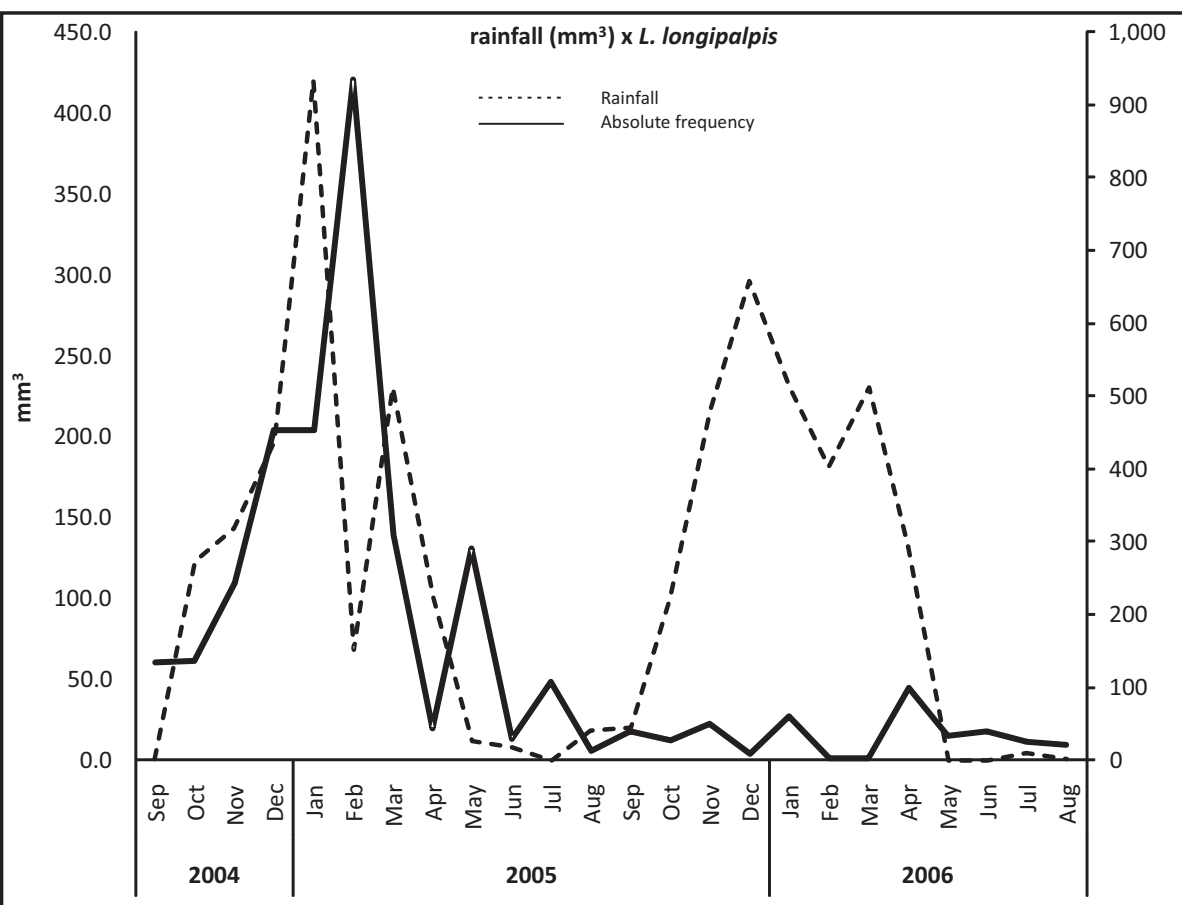

FIGURE 2 - Relationship between the vector density of Lutzomyia longipalpis collected with CDC type light traps and the average rainfall from September 2004 to August 2006 in the town of Barra do Garças-MT. second preceding month $\left(Y_{t-2}\right)$ and on the relative humidity in the same month $\left(X_{t}\right)$ and in the previous month $\left(X_{t-1}\right)$. The corresponding weights are given by the numerical values of the model. Moreover, the same monthly frequency of $L$. longipalpis $\left(Y_{t}\right)$ also depends on other random factors, and the same month and the previous month are represented by $\alpha_{t}$ and $\alpha_{t-1}$, respectively.

The association between the frequency of $L$. longipalpis captured and the variation of rainfall is represented in Figure 2. The annual rainfall was $1,668.9 \mathrm{~mm}, 1,489.6 \mathrm{~mm}$, and $1,406.3 \mathrm{~mm}$ for the years 2004,2005 , and 2006, respectively.

ANOVA applied to verify if the seasons, i.e., dry and wet, interfere with the vector density of $L$. longipalpis provided a p value of 0.00058 $(\mathrm{p}<0.05)$, indicating that there were significant differences for various periods, and the vector density of $L$. longipalpis was highest in the rainy season from November 2004 to March 2005.

When testing the influence of rainfall on relative humidity, there was a significant correlation between rainfall with relative humidity in the same month $(\mathrm{r}=0.72, \mathrm{p}<0.05)$ and in the subsequent 2 months $(\mathrm{r}=0.60, \mathrm{r}=0.50, \mathrm{p}<0.05)$.

\section{DIscussion}

The richness of sandfly species in the neighborhoods studied in the City of Barra do Garças-MT was high ( $\mathrm{D} \alpha=6.65)$, and featured a very diverse population that was comprised of 2 genera and 27 species. The most abundant species were L. longipalpis (44\%), Lutzomyia lenti (Mangabeira, 1938) (18.9\%), Lutzomyia whitmani (Antunes \& Coutinho, 1939) (13.9\%), and Lutzomyia carmelinoi (Ryan Fraiha, Lainson \& Shaw, 1986) (9.1\%). Noteworthy is the finding of 4 species of sandflies of importance to public health, i.e., L. longipalpis, L. whitmani, Lutzomyia flaviscutellata (Mangabeira, 1942), and Lutzomyia wellcomei (Fraiha, Shaw \& Lainson, 1971). However, the species L. lenti and L. carmelinoi are not considered as vectors of leishmaniasis.

The third most abundant species, L. whitmani, is the main vector of american tegumentary leishmaniasis (ATL) in the State of Mato Grosso and in Barra do Garças-MT, being found in peridomestic and indoor areas (V Correa, GBM Lima, MFM Queiroz: unpublished data). This species is in the process of domestication and is widely distributed with greater adaptation to man-made changes to the environment ${ }^{15}$.

Despite the low density of $L$. flaviscutellata and L. wellcomei in the urban area, their presence is of concern given the importance they represent to publichealth.L.flaviscutellata is a common species of forest and halfdomestic environments. Since they are vectors of Leishmania and arboviruses, their preferred habitats are chicken coops, pig pens, corrals, and other attachments of domestic animals and the external and internal walls of human homes ${ }^{15}$.

L. wellcomei, another vector for ATL, has been reported for the first time in Mato Grosso. The presence of this species 
was reported ${ }^{15}$ in the States of Amazonas, Pará, Ceará, Maranhão, and Pernambuco, and is essentially a forest species. Therefore, its presence in urban areas suggests their possible urbanization, and it is thus important to study their biology and ecology.

The altered environments favors adaptation of some species of sandflies especially in peridomiciliary, thereby favoring the transmission of the disease, as evidenced in this study, with the presence of L. longipalpis in the urban areas surveyed in Barra do Garças-MT, confirming the findings of some authors ${ }^{16-18}$.

Our results suggest that the transmission pattern of AVL may be changing from its previous association with occupational or recreational activities, and this may also be associated with its transmission in the peridomestic environment, corroborating the findings of other authors ${ }^{19-21}$.

The transmission of AVL is also influenced by poor sanitation, lack of environmental management, the movement of people and wildlife reservoirs between wild and urban environments, and the existence of dogs infected with Leishmania (Leishmania) infantum chagasi $^{22}$.

The peripheral districts studied have a predominantly lowincome population. In addition, $90 \%$ of the households surveyed raise chickens. As mentioned earlier, the presence of chickens was one of the criteria for choosing the properties in the present study because this promotes the accumulation of organic matter, thereby favoring the breeding of sandflies, and being one of their preferred food sources ${ }^{23,24}$. The presence of chickens in large quantities in the areas surrounding homes appears to be of epidemiological significance, in that it works as a decoy for the vector, keeping it in this environment ${ }^{23}$. Our results confirmed that chickens were a risk factor for the presence of $L$. longipalpis.

Another important condition for the maintenance of AVL in urban areas is the presence of dogs, which are reservoirs of the disease $\mathrm{e}^{23}$, and $70 \%$ of the households surveyed kept a dog. It is important to emphasize that chickens and dogs promote the continuity of the vector and the etiologic agent of the disease, thereby bringing the disease to humans $s^{22,23}$.

The differentiation of L. longipalpis by sex showed a higher capture rate for males, corroborating the findings of other authors ${ }^{17,25}$. This higher ratio can be explained by the natural behavior of the sandflies because males follow females to ensure fertilization.

Factors such as temperature, relative humidity, and rainfall have an influence on sandfly population density, depending on the area analyzed ${ }^{25}$. In the present study, temperature had no influence on the frequency of L. longipalpis. However, relative humidity influenced the vector density of L. longipalpis, corroborating the findings of other authors ${ }^{20,26,27}$.

Moreover, the time series model showed that the relative humidity in the same and previous month influences the population density of L. longipalpis, the same effect was observed for the frequency of the species population, and that the interference was even greater as it persisted from the second preceding month.

By comparing the relative frequency of L. longipalpis in the dry and rainy seasons, we noticed a significant increase in the frequency of $L$. longipalpis during the rainy season, as reported by other authors ${ }^{12,17,18,28-31}$.The rainy season increases air humidity and favors the growth of vegetation that provides shelter and adequate conditions for the reproduction of sandflies ${ }^{32}$.
Peak capture and rainfall did not coincide for the 2 years studied, suggesting that rainfall encourages the growth of the sandfly population, but not excessively so, as reported by other authors ${ }^{25,26}$. The direct effect of large amounts of rain can change the biological cycle of the sandfly. It is possible that excessive rainfall alters the availability of the organic matter that they use for the deposition of eggs and for their larvae to feed on; however, it could also kill the immature flies. Therefore, there seems to be a threshold level of rainfall that is favorable for the reproductive cycle of sandflies.

In the first year of entomological monitoring (September 2004-August 2005), we observed a large number of L. longipalpis in the study area; however, this was followed by a decline in the second year. This fact can also be associated with environmental management (e.g., tree pruning, removal of organic matter, and eliminating some chickens and pigs) that was conducted in the peridomestic environment, as confirmed by other authors ${ }^{5,33}$.

The presence of L. cruzi in the urban area was previously reported in Barra do Garças-MT ${ }^{6}$, but this species was not collected during the 2 years of monitoring. The occurrence of a species in a local community is partially determined by its adaptation to the conditions and available resources and partly by competitive interactions with other species ${ }^{34}$; as these species are very close phylogenetically, both must use the same ecological resources, and competition must occur ${ }^{18}$. Therefore, interspecific competition could explain the absence of $L$. cruzi during this period.

The results indicated a worrying situation for the urban area of Barra do Garças-MT, as L. longipalpis was the most frequent and abundant species, being collected in every month of the year and found in all households surveyed, since it is the main vector of Leishmania (Leishmania) infantum chagasi in Brazil ${ }^{19,35}$. Entomological knowledge about the seasonality and population dynamics of L. longipalpis in Barra do Garças-MT allows the targeting of prevention and control activities for AVL, optimizing financial resources and actions, and thus promoting the strengthening of public health.

The importance of detecting L. longipalpis is the fact that this species is more adapted to the epidemiology of the disease, is widely distributed throughout the country, and is present in areas where $\mathrm{AVL}$ is a constant concern of public health management programs ${ }^{36}$.

The high richness of sandflies found reinforces the importance of further studies in order to raise more qualitative and quantitative information on the transmission cycle of leishmaniasis in the municipality of Barra do Garças-MT.

\section{ACKNOWLEDGMENTS}

We thank the municipal health team for logistical and technical support, especially to the Agents to Combat Endemic Diseases, on behalf of Elis Tagino de Lima and Andrea de Menezes, who collaborated with the collections, at Central Level/SES/MT, and also for logistical and technical support, especially in the identification of the species collected; and the other technicians of the Regional Health Barra do Garças who directly or indirectly contributed to the creation of this monitoring program.

\section{CONFLICT OF INTEREST}

The authors declare that there is no conflict of interest. 


\section{FINANCIAL SUPPORT}

Secretaria Municipal de Saúde de Barra do Garças-MT and SES/MT

\section{REFERENCES}

1. World Health Organization (WHO). Leishmaniasis [Internet]. [Cited 2011 January 26]. WHO Available from: http://www.who.int/leishmaniasis/.

2. Ministério da Saúde. Leishmaniose Visceral: Descrição da doença [Internet]. Brasília: Ministério da Saúde; [Cited 2011 February 8]. Available from: http://portal.saude.gov.br/portal/saude/profissional/visualizar_texto. cfm?idtxt=31934.

3. Mestre GLC, Fontes CJF. A Expansão da epidemia da Leishmaniose Visceral no Estado de Mato Grosso, 1998-2005. Rev Soc Bras Med Trop 2007; 40:42-48.

4. Banco de Dados do Sistema Único de Saúde (DATASUS) [Internet]. Brasília: Ministério da Saúde; [Cited 2011 January 26]. Available from http://189.28.128.178/sage/?saude=http\%3A\%2F\%2F189.28.128.178\%2Fsa ge\%2F\&botaook=OK\&obj=http\%3A\%2F\%2F189.28.128.178\%2Fsage\%2F/.

5. Ministério da Saúde. Secretaria de Vigilância em Saúde. Departamento de Vigilância Epidemiológica. Manual de vigilância e controle da Leishmaniose Visceral. Brasília: Ministério da Saúde; 2006.

6. Missawa NK, Lima GBM. Distribuição espacial de Lutzomyia longipalpis (Lutz \& Neiva, 1912) e Lutzomyia cruzi (Mangabeira, 1938) no estado de Mato Grosso. Rev Soc Bras Med Trop 2006; 39:337-340.

7. Instituto Brasileiro de Geografia e Estatística (IBGE) IBGE Cidades [Internet]. Brasília: IBGE; [Cited 2010 January 28] Available from http://www.ibge.gov. $\mathrm{br} /$ cidadesat/topwindow.htm?1/.

8. Prefeitura Municipal de Barra do Garças-MT. Estatísticas do Município [Internet]. Barra do Garças: Prefeitura Municipal; [Cited 2011 January 31]. Available from http://barradogarcas.com/2010/?Secao=Municipio\&Pg=Estatisticas/.

9. Köppen W. Climatologia. Buenos Aires: Ed. Fundo de Cultura Econômica; 1948

10. Souza JCC. Geografia Regional: Centro-Oeste e Mato Grosso. $4^{a}$ ed. Cuiabá: Atalaia; 1995

11. Marcondes CB. Entomologia médica e veterinária. São Paulo: Atheneu; 2001.

12. Young DG, Duncan M. Guide to the identification and geographic distribution of Lutzomyia sand flies in Mexico, the West Indies, Central and South America (Diptera: Psychodidae). Florida-USA: Memoirs of the American Entomological Institute; 1994.

13. Rodrigues WC. DivES: Diversidade de espécies. Software e guia do usuário [Internet]. Version 2.0. Comendador Levy Gasparian: Entomologistas do Brasil; 2009. [Cited 2011 February 9] Available from: http://www.ebras.bio.br/dives.

14. Brockwell PJ, Davis RA. Times Series: Theory and Methods. $2^{\text {nd }}$ edition. New York: Springer Verlang; 1991.

15. Aguiar GM, Medeiros WM. Distribuição e habitats. In: Rangel EF, Lainson R, editors. Flebotomíneos do Brasil. Rio de Janeiro: Fundação Oswaldo Cruz; 2003. p. 207-255.

16. Oliveira AG, Falcão AL, Brazil RP. Primeiro encontro de Lutzomyia longipalpis (Lutz \& Neiva, 1912) na área urbana de Campo Grande, MS, Brasil. Rev Saude Pública 2000; 34:654-6555.

17. Oliveira AG, Andrade-Filho JD, Falcão AL, Brazil RP. Estudo de flebotomíneos (Diptera, Psychodidae, Phlebotominae) na zona urbana da cidade de Campo Grande, Mato Grosso do Sul, Brasil, 1999-2000. Cad Saude Publica 2003; 19:933-944.

18. Almeida PS, Nascimento JC, Ferreira AD, Mizão LD, Portes F, Miranda AM, et al. Espécies de flebotomíneos (Diptera, Psychodidae) coletadas em ambiente urbano em municípios com transmissão de Leishmaniose Visceral do Estado de Mato Grosso do Sul, Brasil. Rev Bras Entomol 2010; 54:304-310.

19. Gontijo CMF, Melo MN. Leishmaniose Visceral no Brasil: quadro atual, desafios e perspectivas. Rev Bras Epidemiol 2004; 7:338-349.

20. Monteiro EM, Silva JCF, Costa RT, Costa DC, Barata RA, Paula EV, et al Leishmaniose Visceral: estudo de flebotomíneos e infecção canina em Montes Claros, Minas Gerais. Rev Soc Bras Med Trop 2005; 38:147-152.

21. Oliveira ALL, Paniago AMM, Dorval MEC, Oshiro ET, Leal CR, Sanches M, et al. Foco emergente de Leishmaniose Visceral em Mato Grosso do Sul. Rev Soc Bras Med Trop 2006; 39:446-450.

22. Maia-Elkhoury ANS, Alves WA, Sousa-Gomes ML, Sena JM, Luna EA Visceral Leishmaniasis in Brazil: trends and challenges. Cad Saude Publica 2008; 24:2941-2947.

23. Dias FOP, Lorosa ES, Rebelo JMM. Fonte alimentar sanguínea e a peridomiciliação de Lutzomyia longipalpis (Psychodidae, Phebotominae). Cad Saude Publica 2003; 19:1373-1380

24. Missawa NK, Lorosa ES, Edelberto SD. Preferência alimentar de Lutzomyia longipalpis (Lutz \& Neiva, 1912) em área de transmissão de leishmaniose visceral em Mato Grosso. Rev Soc Bras Med Trop 2008; 41:365-368.

25. Dias ES, França-Silva JC, Silva JC, Monteiro EM, Paula KM, Gonçalves CM, et al Flebotomíneos (Diptera: Psychodidae) de um foco de leishmaniose tegumentar no Estado de Minas Gerais. Rev Soc Bras Med Trop 2007; 40:49-52.

26. Macedo ITF, Bevilaqua CML, Morais NB, Sousa LC, Linhares FE, Amóra SSA et al. Sazonalidade de flebotomíneos em área endêmica de Leishmaniose Visceral no município de Sobral, Ceará, Brasil. Ciência Animal 2008; 18:67-74.

27. Barata RA, Silva JCF, Costa RT, Fortes-Dias CL, Silva JC, Paula EV, et al Phlebotomine sand flies in Porteirinha, an area of American Visceral Leishmaniasis transmission in the State of Minas Gerais, Brazil. Mem Inst Oswaldo Cruz 2004; 99:481-487.

28. Rebêlo JMM. Freqüência horária e sazonalidade de Lutzomyia longipalpis (Diptera: Psychodidae: Phlebotominae) na Ilha de São Luís, Maranhão, Brasil Cad Saude Publica 2001; 17:221-227.

29. Silva EA, Andreotti R, Honer MR. Comportamento de Lutzomyia longipalpis, vetor principal da Leishmaniose Visceral Americana, em Campo Grande, Estado do Mato Grosso do Sul. Rev Soc Bras Med Trop 2007; 40:420-425.

30. Marinho RM, Fonteles RS, Vasconcelos GC, Azevêdo PCB, Moraes JLP, Rebêlo JMM. Flebotomínes (Diptera, Psychodidae) em reservas florestais da área metropolitana de São Luís, Maranhão, Brasil. Rev Bras Entomol 2008; 52:112-116.

31. Nunes VLB, Galati EAB, Cardozo C, Rocca MEG, Andrade ARO, Santos MFC, et al Estudo de flebotomíneos (Diptera, Psychodidae) em área urbana do município de Bonito, Mato Grosso do Sul, Brasil. Rev Bras Entomol 2008; 52:446-451.

32. MichalskyEM, França-Silva JC, Barata RA, Silva FO, Loureiro AMF, Fortes-Dias CL, et al. Phlebotominae distribution in Janaúba, an área of transmission for visceral leishmaniasis in Brazil. Mem Inst Oswaldo Cruz 2009; 104:56-61.

33. Oliveira GMG, Figueiró Filho EA, Andrade GMC, Araújo LA, Oliveira MLG Cunha RV. Flebotomíneos (Diptera: Psychodidae: Phlebotominae) no município de Três Lagoas, área de transmissão intensa de Leishmaniose Visceral, Estado de Mato Grosso do Sul, Brasil. Rev Pan-Amaz Saude 2010; 54:304-331.

34. Ricklefs RE. A Economia da Natureza. $5^{\text {a }}$ ed. Rio de Janeiro: Guanabara Koogan 2003.

35. Lainson R, Rangel EF. Ecologia das Leishmanioses. In: Rangel EF, Lainson R, editors. Flebotomíneos do Brasil. Rio de Janeiro: Fundação Oswaldo Cruz; 2003. p. 311-336.

36. Santos SO, Arias JR, Hoffmann MP, Furlan MBG, Ferreira WF, Pereira C, et al. The presence of Lutzomyia longipalpis in a focus of American Visceral Leishmaniasis where the only proven vector is Lutzomyia cruzi. Corumbá, Mato Grosso do Sul State. Rev Soc Bras Med Trop 2003; 36:633-634. 